\title{
La biografía en la actual historiografía contemporánea española
}

\author{
María Gloria Núñez Pérez*
}

\begin{abstract}
RESUMEN ABSTRACT
En los años noventa se produce en la In the nineties a resurgence of historiografia contemporánea española historical biography has appeared on un resurgimiento de la biografía histórica. El artículo explica este hecho mendiante la descripción del contexto sociocultural que le rodea y a través del examen de las investigaciones biográficas plasmadas en tesis the Spanish modern historiography. This article explains this fact using a description of the sociocultural context and a survey of the biographical researchs materialized in doctoral thesis and several publications.
\end{abstract} doctorales y diversas publicaciones.

PALABRAS CLAVE Biografias. España. Historia contemporánea. Historia política. Siglos $x I x$ y $x x$. Historiografia. Años 1990-1997.

KEY WORDS

Biography. Spain. Modern history. Political history. Centuries $X I X, X X$. Historiography. Years 1990-1997.

Biografías, historias de vida, memorias, autobiografías, diarios, recuerdos... en los útimos años los medios de comunicación han reflejado la marea de publicaciones que describian o indagaban sobre el universo de los acontecimientos generados por una persona o sucedidos en torno a ella.

Desde la perspectiva de la historiografía contemporánea ha ido surgiendo una cantidad apreciable de investigaciones que convertian a personajes individuales en el centro del discurso histórico. Dentro de los medios

* UNED. 
académicos este tipo de estudios ha sido englobado dentro de la tendencia calificada genéricamente como retorno del sujeto y más concretamente como resurgimiento de la biografía histórica.

¿Cúales son las circunstancias socioculturales donde nace y se desarrolla la biografía histórica? ¿Qué manifestaciones, formas y caracteristicas presenta lo biográfico y en que ámbitos se produce? Antes de pasar a contestar estas preguntas voy a referirme sucíntamente al marco conceptual de lo biográfico y a los antecedentes históricos más significativos del género porque creo que así la biografía histórica actual podrá ser valorada con más precisión.

\section{MARCO CONCEPTUAL Y ANTECEDENTES HISTORIOGRÁFICOS}

Comúnmente la biografía se define como la historia de la vida de una persona. Su realización precisa de la recogida de datos sobre los hechos y circunstancias que jalonaron esa vida, información procedente del biografíado -entrevistas, conversaciones, archivo privado, correspondencia, diarios, memorias, obras producidas, iconografía, objetos personales-. de las personas que tuvieron relación con él y de cualquier material escrito, oral, fotográfico o filmado que sirva para aportar luz a la trayectoria vital. La biografía forma parte de la historiografía ya que esta disciplina examina el conjunto de hechos protagonizados por hombres y mujeres en tiempos anteriores. Además desde la antigüedad la biografía ha participado de una forma u otra en las sucesivas corrientes historiográficas.

Existen diferentes formas de biografías o historias de vida según se atienda a unos u otros criterios. La biografía histórica es el relato encadenado lógicamente a partir de datos suficientemente probados y contrastados. Si son reflexiones libres razonablemente efectuadas es un ensayo biográfico, si interviene decisivamente la imaginación y la fantasía sobre una base de acontecimientos realmente ocurridos es una biografia novelada, si se limita a exponer brevemente los rasgos y acontecimientos más significativos en la vida de una persona es una nota lexicográfica.

La biografía puede limitarse a la exposición de las obras realizadas por una persona, dejándolas aisladas de su escenario histórico, o dar fundamental importancia al tiempo donde vivió, relacionando las circunstancias históricas con las realizaciones materiales y espirituales del individuo examinado. Según la narración se fije en unos u otros aspectos de la vida, resulta una biografía pública, privada, psicológica, política, intelectual, etc. Si el protagonista del relato emitió un dictamen a favor o en contra del relato 
publicado, se denomina biografía autorizada o no autorizada respectivamente a cada posibilidad.

Calificamos como autobiografía al texto donde el autor relata su propia vida, es el documento que por defininición contiene más carga de subjetividad. Relato de vida se llama a la exposición oral que una persona hace de su propia vida. Prosopografía es el estudio colectivo de las vidas de un grupo de personajes históricos ${ }^{1}$.

La biografía puede referirse a un hombre común - a la personalidad modal o tipo que cristaliza en muchos de sus coetáneos- o al hombre marginal, excepcional, héroe o víctima, modelo o precursor de nuevos tiempos. Puede estar escrita con distanciamiento del autor o sesgada desde el panegírico y la simpatía, al anatema y a la antipatía. A veces su intención es rehabilitar a un personaje antes denostado o al contrario, derrumbar su fama. Provocar escándalo y sensacionalismo, por medio de la revelación de los sucesos más escabrosos y ocultos en la vida de un hombre o mujer públicos, es también una forma de biografía que alcanza éxitos de venta en nuestra sociedad mercantilista y ávida consumidora de las vidas privadas de los personajes populares.

La biografía como género apareció en la antigüedad grecorromana aunque se diferenciaba de la historia en que mientras la primera trataba de explicar la personalidad y el carácter de un hombre a través de sus acciónes, la segunda se centraba en relatar acontecimientos y acciones en tanto habían ocurrido y eran importantes para conocer lo que en realidad pasó.

Plutarco de Queronea (50-125 d. C.), considerado el más ilustre biógrafo de la antigüedad, autor de Vidas paralelas, indica:

No escribimos historias, sino vidas; ni es en las acciones más ruidosas en las que se manifiestan la virtud o el vicio, sino que muchas veces un hecho de un momento, un dicho agudo y una niñería sirve más para aclarar un carácter que batallas en que mueren millares de hombres, numerosos ejércitos y sitios de ciudades. Por tanto, así como los pintores toman para retratar las semejanzas del rostro y aquella expresión de ojos en que más se manifiesta la índole y el carácter, cuidándose poco de todo lo demás, de la misma manera debe a nosostros concedérsenos el que atendamos más a los indicios del ánimo, y que por ellos dibujemos la vida de cada uno, dejando a otros los hechos de grande aparato y los combates?

En el Congreso internacional de Ciencias Históricas celebrado en 1990 una de las comunicaciones estableció, barajando diversos criterios, diez formas de biografias: notas lexicográficas, vidas y obras, vidas y tiempos, ensayos biográficos, autobiografías, comprensión del interiol, biografías noveladas, psicoanálisis del personaje, prosopografías y testimonios orales. Véase ENGELBERG y SCHLEIER 1992.

PlutaRco, 1970, p. 23. 
Esto no impide que Plutarco utilice el método histórico ya que maneja gran cantidad de fuentes planteándose, en ocasiones, su autenticidad y alude a la dificultad de capturar la verdad. Su relato tiene una progresión cronológica con objetivos moralizantes y ejemplarizantes, característicos también de la historiografía grecorromana.

Desde sus orígenes griegos la biografía, aunque tenía un método propio centrado en relatar, explicar e interpretar la vida de una persona fijándose en los hechos que revelaban su carácter y personalidad, participaba en el método histórico peculiar de su época. Lo mismo ocurrió en el medievo cuando la historiografía narró hechos fabulosos como reales y la hagiografía fue un género de amplia expansión, caracterizado por la exposición de los espectaculares prodigios que jalonaban las vidas de esos humanos que se convertían en santos. La Leyenda áurea del dominico italiano Jacobo de la Vorágine (1228-1298), texto de amplia circulación en siglos posteriores, es una recopilación de relatos esquemáticos sobre la vida de santos, llenos de personajes humanos y divinos que realizan milagros asombrosos. En las crónicas medievales, centradas en las gestas de grandes personajes - reyes o nobles - también se superponen los elementos naturales y fabulosos. Por ejemplo la Crónica de Muntaner (siglo XIV), que narra los hechos de algunos de los reyes de la casa de Aragón, comienza con la narración semimaravillosa del alumbramiento de Jaime el Conquistador.

A partir del renacimiento la biografía como la historia va abandonando los sucesos fabulosos, ateniéndose a los hechos suficientemente documentados y verificados. Inglaterra es la cuna de la biografía moderna, la que basada en abundante información contrastada, describe la vida pública y privada de un personaje, tratándole de conocer en toda su personalidad, incluidos los aspectos íntimos. James Boswell en Vida de Samuel Johnson (1791) relata la existencia práctica, el día a día del escritor británico, que era también su amigo, proporcionando el retrato de un hombre con un carácter orgulloso, tenaz y voluntarioso y un espíritu moralista intransigente que es a la vez el retrato de un pueblo y de una época. El desarrollo ininterrumpido de la biografía inglesa, que llega a la actualidad ${ }^{3}$, se ha atribuido a la tradición empirista y a la vez elitista del pueblo anglosajón, más interesado por la concreción y el individuo diferente por su excentricidad o genialidad que por la abstracción y las masas humanas. También, y unido a lo anterior, al espí-

La prensa española también se ha hecho eco del continuo fluir biográfico en el mundo anglosajón. Por ejemplo en El País, Madrid, 18-11-1995. 
ritu protestante y su curiosidad por desvelar la intimidad del corazón humano.

En el siglo xIx, Leopoldo von Ranke, el representante por antonomasia del historicismo que renovó la práctica historiográfica con los principios de objetividad, recopilación exhaustiva y crítica de las fuentes, consideró a la biografía como parte de la historia. Creía que la biografía era el encuentro entre una personalidad con sus cualidades innatas y las condiciones en que nace y se desenvuelve. De la confluencia entre ambos, persona y circunstancias, surgía la vida humana con sus vicisitudes, pasiones, triunfos y desastres. En el prólogo a Historia de Wallenstein (1869) indica:

Las decisiones de los hombres parten siempre de las posibilidades que las condiciones generales les ofrecen; las realizaciones importantes reclaman siempre la cooperación de los elementos homogéneos del mundo en torno; tal parece como si el hombre no fuese más que una criatura de su tiempo, el exponente de un mundo general existente al margen de él. Pero, por otra parte, no debe olvidarse que las personas viven, a su vez, dentro de un orden moral universal, en el que pueden afiarmarse en toda su plenitud; cobran en él una vida propia y sustantiva, de una gran fuerza original. A la par que, como suele decirse, retratan y representan a su tiempo, dejan su huella en él y contribuyen a marcarle el rumbo por la fuerza de su impulso innato e interior ${ }^{4}$.

Pero Ranke, a diferencia de los ingleses, no daba mucha importancia al examen de los aspectos íntimos y privados de una vida. Pensaba que el carácter de un hombre histórico se cifraba y definía menos en sus costumbres, modos de vivir o rasgos fortuitos, que en los actos por él realizados en los grandes momentos, en las ocasiones grandes ${ }^{5}$.

En contraposición a esta biografía historicista que minusvaloraba los detalles íntimos, surge en la primera mitad del siglo xx una corriente que creía que un acto, un gesto o un ademán incosciente podía constituir un signo clave para conocer el carácter y temperamento de un persona tal como valoraba Plutarco. Además consideraba importante la capacidad de comprensión y la penetración psicológica del biógrafo para desentrañar y clarificar una personalidad. Los representantes de esta tendencia estaban en la onda de la historiografía antipositivista, la que provenía de los neokantianos (Windelband, Rickert, Droysen) y vitalistas (Dilthey) quienes juzgaaban que la historia y las ciencias sociales eran fundal- 
mentalmente interpretación y comprensión mientras las ciencias naturales eran explicación ${ }^{6}$.

El alemán Emil Ludwig, autor de biografias de gran éxito editorial sobre Napoleón, Bismarck, Guillermo II de Alemania y otros grandes personajes, consideraba imposible la objetividad histórica, defendida por la escuela de Ranke, ya que la simple selección de unos hechos implicaba subjetividad. Pensaba que una biografía completa debía presentar al mismo tiempo la vida pública y la privada, la vida activa e inactiva, sin tomar una de ellas por más importante que la otra ${ }^{7}$. Ludwig creía que algunas escenas, detalles o anécdotas de una vida podían, a modo de relámpago, iluminarlas en su totalidad. Por ejemplo, creía que la grandeza de Napoleón se había manifestado de la forma más palmaria y evidente, cuando, prisionero en el buque Bellerophon, apareció sobre cubierta, en un puerto inglés, y se destocaron miles de curiosos en los botes esparcidos a su alrededor mientras, él sólo, el vencido, quedó cubierto ${ }^{8}$. No obstante Ludwig consideraba que la biografía debía articularse sobre datos fidedignos. Llegó a decir que debería exigírsele responsabilidad "al que inventa tratando de la verdad histórica, lo mismo en el sentido de añadir que en el de ocultar; al biógrafo que excluye, trueca o completa caprichosamente un documento único esencial debería retirársele la venia scribendi, por atentado a la seguridad pública» ${ }^{9}$.

Biógrafos coetáneos a Emil Ludwig, como el inglés Lytton Strachey, el francés André Maurois o el austriaco Stefan Zweig, fueron considerados por historiadores positivistas del momento más cerca del arte literario y de la novela que de la historia, porque, aunque utilizaban una base documental fidedigna, exageraban o sobrevaloraban actitudes y escenas, cargando el acento épico o dramático sobre el personaje, y abusaban de las descripciones psicológicas. Hoy día algunas de sus obras se consideran modélicas aún teniendo en cuenta que contienen una no despreciable carga de subjetividad, rasgo que los propios autores reconocen. En Victorianos eminentes (1918) Strachey, utilizando entre otras fuentes los diarios privados, muestra con agudas observaciones los claroscuros del comportamiento humano, lugares donde hasta los más ilustres dejan de ser ejemplares, revelando una alta sociedad inglesa llena de egoismo, ambición e

- El nacimiento y evolución de la historiografía antipositivista y sus diferencias con la historiografía positivista explicativa en NUÑEZ, 1995, pp. 41-54.

LUDWIG, 1962, p. 21

Idem, p. 22

Idem, p. 15 
incompetencia. En La reina Victoria (1921) desmitifica al personaje, fijándose en sus excentridades y manías, retratando a la vez a los personajes y políticos que rodeaban a la reina y que hicieron de Inglaterra un imperio.

\section{INDIVIDUALISMO Y POSMODERNIDAD}

A mediados del siglo actual, desde los años cincuenta y hasta los setenta, triunfó en el Occidente una historiografía de tipo positivista explicativo, una historiografía centrada en analizar rasgos comunes y repetitivos, en descubrir, resaltar y cuantificar materiales que luego el investigador ordenaba y explicaba en una estructura, sistema o modelo anónimos donde quedaba reflejaba la realidad descubierta. Dejaba en lugar secundario el análisis de los fenómenos históricos en su condición de irrepetibilidad, en el ser efectuados por individuos singulares.

El objetivo de esta historiografía radicaba en buscar constantes, regularidades en la sucesión de acontecimientos y por ello consideraba menos importante la descripción pormenorizada de un acontecimiento concreto - la comprensión exhaustiva del sujeto que lo producia. El historiador debía descubrir y explicar el hilo conductor de concatenaciones de hechos partiendo de hipótesis previamente formuladas y que debia probar con datos suficientes.

Era una tendencia historiográfica que había ido construyéndose desde principios del siglo $x x$ y que defendía un mismo método de conocimiento para las ciencias humanas y naturales, frente a la corriente antipositivista que predicaba diferentes métodos para cada tipo de ciencias ${ }^{10}$.

La biografía en tanto se centraba en la vida de una persona quedó relegada por la historiografía positivista explicativa pues consideraba que una vida por importante que hubiera sido no explicaba una estructura económica, una revolución o un sistema político. Los relatos biográficos de Lytton Strachey, Emil Ludwin o André Maurois fueron considerados más dentro de la literatura que de la historia, una acusación formulada también por los historicistas. Muchos de los hechos que relataban estos biógrafos eran díficiles de demostrar atendiendo únicamente a las pruebas documentales ¿Un acto fortuito podía considerarse una prueba para establecer un carácter? ¿Cómo probar los sentimientos y pasiones que el bio-

10 Lawrence Stone denomina "historia científica" a la "historia positivista explicativa", en STONE 1986, pp. 95-120. Peter Burke la denomina «nueva historia», en BuRkE, 1993, pp. $11-37$. 
gráfo comprendia que, en ciertas circunstancias, habian experimentado los protagonistas? Los positivistas explicativos abandonaron estas cuestiones de comprensión que no encajaban en sus marcos teóricos y se dedicaron a los datos más consistentes, fáciles de identificar, medir y probar en las fuentes.

Pero conforme en los años setenta la historiografía positivista explicativa va entrando en crisis, porque sus métodos no conseguian las esperadas conclusiones definitivas e incuestionables, va surgiendo una historiografía con renovada vocación de totalidad que considera otras fuentes y las contempla e investiga a la luz de nuevas hipótesis y metodologías.

Es una historiografía que vuelve su mirada a hechos, factores o ámbitos antes desdeñados por la historiografía positivista explicativa. Su discurso histórico se define por adoptar múltiples hipótesis, metodologías y materiales documentales. Ha incorporádo renovándolos, métodos y temáticas considerados característicos de la historiografía tradicional como la narratividad y el interes por lo político, el acontecimiento y el individuo ${ }^{11}$.

La tendencia hacia la individuación, hacia el hombre singular e irrepetible que, en una dimensión cronológica única, actúa, piensa, desea, imagina y recuerda, la denominada historia con personas, ha cristalizado en la biografía que ahora se presenta como un camino para, desde una óptica personificada, comprender y entender una época del mismo modo que, por ejemplo, las series estadísticas de precios proporcionadas por la historia económica nos sirve para explicar la evolución económica ${ }^{12}$.

\footnotetext{
11 Una muestra de la actual variedad historiográfica en los diversos y variopintos textos presentados al congreso internacional La historia a debate, celebrado en 1993. En BARROS, 1995.

12 Son muchos los enfoques hacia el individuo que adopta la historiografía actual. Desde la antropologia histórica, la historia de las mentalidades, la historia popular y la nueva historia cultural se examina la vida de los hombres pertenecientes a las clases inferiores, el hombre común, los marginados o excluidos y las manifestaciones de la personalidad. La historia de las mujeres se ha desarrollado fijándose en una categoría de personas prácticamente olvidadas por el discurso histórico positivista explicativo. La historia oral ha dirigido sus indagaciones en las entrevistas a personas concretas, generalmente los más desfavorecidos cuyo testimonio si no, se hubiera perdido en los abismos del tiempo. La historia del tiempo presente utiliza a los testigos de los acontecimientos y ha abierto un nuevo ámbito de investigación: la memoria histórica de los hombres y mujeres de hoy. La historia de la vida privada o intima, abordada por historiadores como Duby o Zeldin, intenta descubrir, más allá de la abstracción, la experiencia ordinaria de los hombres, quiere conocer las diversas facetas de su privacidad e intimidad, cómo se han enfrentado a problemas como la incomunicación, el odio, la soledad o el desamor. La microhistoria hace hincapie en la libertad de elección de la gente corriente, en su capacidad para sacar partido de sistemas más o menos opresivos. La psicohistoria explica las acciones de los hombres en función de sus intenciones conscientes o incoscientes. La nueva historia política considera decisivo analizar las decisiones tomadas por las personas agentes del poder para la explicación del devenir político. Diversas
} 
La línea de estudios en torno al individuo ha sido calificada como el retorno del sujeto y se localiza dentro de nuestra época, la denominada posmodernidad -término hecho famoso desde 1979 por el filósofo Lyotard ${ }^{13}$ - donde el análisis, comprensión y explicación de lo individual es una muestra paradigmática de la pluralidad y la complejidad del mundo competitivo e individualista en que vivimos. Una sociedad que no cree en ninguna certeza absoluta, a no ser la de considerar que toda realidad sólo se puede conocer fragmentaria y provisionalmente sin que se pueda predecir de forma absoluta su evolución. Estamos en una organización humana ya no estructurada en órdenes, estamentos o clases como en épocas anteriores. Ahora la sociedad postindustrial, término acuñado en 1973 por el sociólogo americano Daniel Bell ${ }^{14}$, está formada por individuos dispersos, descentrados, libres para afirmarse frente a cualquier tradición o conformismo social y vivir para su sóla satisfación hedonista sin referencia a los grandes discursos de la modernidad tales como la importancia de la razón para conseguir la felicidad, la revolución como forma de conseguir la emancipación y la libertad, el bienestar universal a través del progreso económico.

Pero si la posmodernidad rechaza los grandes relatos legitimadores porque no han conseguido la mejora de la humanidad que se proponian, se queda en la pluralidad de los pequeños relatos o justificaciones parciales e individuales que contienen un valor limitado ${ }^{15}$.

La biologia también ha dado radical importancia a la individualidad, estableciendo la diversidad genética de todos los individuos, presentes, pasados y futuros. El conjunto de genes es al mismo tiempo la señal de identidad y diferenciación aunque el individuo sea un producto del azar pues la selección natural opera sobre las mutaciones aleatorias de los genes ${ }^{16}$.

En el ámbito de la teoría del conocimiento el triunfo de lo concreto individual tiene proyección en el constructivismo radical. Esta epistemolo-

consideraciones sobre la tendencia a la individuación pueden verse en MORALES, 1993, pp. 229 250. Algunas de las nuevas historiografías centradas en el individuo en BURKE, 1993 y ANDRÉS, 1993. La acción social o actividad de los agentes humanos como objeto de la ciencia histórica en GONZALEZ, 1996.

3 LYOTARD, 1986.

14 BELL, 1991.

Lyotard en Moralidades posmodernas (1996) reune una serie de historias de vida sin pretensiones ejemplarizantes, su objetivo es mostrar el transcurrir de algunas vidas y nada más, porque el ser humano es simplemente una formación material energética necesariamente transitoria pues depende de unas condiciones de la vida terrestre que no son enternas. La formación humana desaparecerá y aparecerá otro ser no más perfecto sino más adaptado al nuevo entorno.

16 MONOD, 1970. 
gía de la posmodernidad defiende que no hay observaciones que puedan postularse con independencia del investigador pues el objeto y el sujeto se confunden, están indisolublemente unidos. La objetividad es la ilusión de que las observaciones se pueden hacer sin observador dice $\mathrm{H}$. von Foerster, uno de los fundadores de la teoria, sentando una ruptura con la ciencia clásica que daba por supuesto una realidad objetiva independiente del observador ${ }^{17}$.

Ahora es cuando la filosofía vuelve a repensar la cuestión del sujeto en términos conceptuales y sociológicos. Un sujeto que a lo largo de la contemporaneidad ha sido definido de varias forma, desde el ser soberano y libre, dueño de sí y capaz de autodeterminación (concepción clásica y de los ilustrados), a «voluntad de poder» (Nietzsche, Heidegger), ser escindido entre la razón consciente y el subconsciente (Freud), configurado por el lenguage (Wittgenstein) o máquinas no triviales caracterizadas por recordar el pasado y operar holísticamente en el presente, o lo que es lo mismo, cambiar con la experiencia acumulada y dar lugar a comportamientos imprevisibles $(\mathrm{H}$. von Foerster). La filosofía en la posmodernidad replantea la identidad del sujeto, en un presente donde se produce una explosión de exigencia de autonomía y autodeterminación por parte de toda clase de colectivos - mujeres, jóvenes, homosexuales, emigrantes, disminuidos, jubilados... - y del pleno reconocimiento legal y social de la condición de individuo diferente ${ }^{18}$. El sociólogo Alain Touraine propugna en sus últimos trabajos la aparición de un sujeto en términos de actor social que se mueva entre los conflictos y que trate de instaurar el valor de la subjetividad ${ }^{19}$.

En la literatura hay un renacimiento de la subjetividad. En nuestro país el fenómeno se manifiesta en la proliferación de relatos autobiográficos y en la edición de novelas que fuenden ficción y examen de la propia identidad como En los reinos de Taifas (1987) de Juan Goytisolo y Beltenebros (1995) de Múñoz Molina ${ }^{20}$. Ángel G. Loureiro justifica el impulso del género autobiográfico fuera y dentro de nuestras fronteras en que en él confluyen los debates filosóficos y literarios sobre el yo, el mundo y el texto. A través de la autobiografía se abordan conceptos fundamentales en el pensamiento de hoy: sujeto, historia, poder, memoria, representación, simulación, etc. ${ }^{21}$.

Textos pertenecientes a pensadores adscritos a la teoria constructivista radical como $N$. lummann, E. Morin, S. J. Schmidt, F. B. Simon, H. Maturana y F. Varela en Watzlawick y Krieg, 1994. La obra es un homenaje a Heinz von Foerster.

18 La cuestión del individuo en la filosofia actual en CRUz, 1993 y 1996 y OLLIVIER, 1995.

19 TOURAINE, 1993.

20 Navajas, 1996.

2. LOUREIRO, 1991, pp. 2-8 
Desde 1975 ha aumentado significativamente la publicación de textos autobiográficos. El catálogo de la colección La autobiografia de la editorial Megazul-Endymion señala que en España desde 1975 a 1995 se han editado más, que en todos los siglos anteriores ${ }^{22}$. Uno de los motivos es que aquí coincide el final del franquismo con una revitalización del género en todo el mundo dentro de la corriente de vuelta a lo personal y privado. El cambio de régimen y la libertad de expresión en los años setenta llevó a la necesidad de la explicación y exculpación públicas, a la justificación de actuaciones personales que es el motivo principal de las memorias de quienes vivieron apasionadamente la república, la guerra y el franquismo de uno u otro lado. En los últimos años los libros de memorias, diarios o novelas solapadamente autobiográficas aparecen por todas partes, desde Carrillo a Pérez Reverte o Manuel Vicent pasando por Tarancón, R. Alberti, Daniel Múgica, Jesús Pardo, Trapiello, etc. En la prensa diaria se escriben columnas a modo de diarios o dietarios como es el caso de Umbral y Arrabal en El Mundo.

En la novela histórica ${ }^{22 b i s}$ encontramos la mezcla de subjetividad y objetividad, las dos caras de la realidad que la posmodernidad ha fundido difuminando sus límites precisos. La novela histórica contiene la ambigüedad posmoderna. Aquí el novelista entrelaza lo imaginario y lo real, utiliza su particular fantasía sobre un marco de acontecimientos básicos proporcionados por la documentación histórica. En España los grandes éxitos de la novela histórica se produjeron desde los años ochenta con obras como Memorias de Adriano de M. Yourcenar o Yo Claudio de R. Graves. También han triunfado las novelas de autores españoles como Antonio Gala, Terence Moix, Nestor Luján, Manuel Vázquez Montalbán o Carlos Rojas. El gran público lector encontraba ahí las vicisitudes sufridas por hombres «reales", los sentimimientos, las pasiones, el drama o la intriga que siempre interesa al gran público en mucha mayor medida que la historia dedicada al análisis de estructuras sociales o una literatura de compleja introspección.

La expansión de lo individual, del personaje y del acontecimiento queda patente sobre todo a través de los medios de comunicación de masas, en la prensa, radio y televisión. Proliferan las noticias, las entrevistas o los reportajes donde los periodistas informan sobre lo que hacen o como viven

\footnotetext{
2. Sobre la autobiografía contemporánea española hasta 1975 véase FERNANOEZ, 1991, pp. 2023. Desde 1975 a 1991 en ROMEFA, 1991 p. 170-184. La Universidad de Barcelona fundó en 1989 la Unidad de Estudios Biográficos para el estudio y recopilación de textos autobiográficos en España.

zzis Romera, Gutiéraez, Garcia-Pages, 1996.
} 
pública y privadamente las personas que han llegado a alcanzar el estatus de populares. Los medios persiguen relatar y retratar la vida privada de los personajes públicos, los famosos, porque a la gente le interesa conocerlos en todas sus facetas, más incluso la vida íntima que la exterior, y cuanto más escondido, escandaloso o fuera de la norma son los hechos desvelados, es mayor el índice de audiencia que despierta.

La corriente personalista ha llegado a los propios historiadores que también relatan sus trayectorias profesionales y vitales. A finales de los años ochenta apareció en Francia el libro dirigido por Pierre Nora donde conocidos historiadores relataban su experiencia autobiográfica, lo que Nora llamaba ego-historia. Por esas fechas en España, durante las sesiones del cuarto coloquio de Segovia sobre historia contemporánea de España, el historiador de la economía Gabriel Tortella exponía unas reflexiones autobiográficas sobre su método y trabajo para avanzar en el conocimiento de su especialidad. Luego se han publicado experiencias autobiográficas de Fraser, Duby, Beloff, Jackson, Tusell, Le Goff, etc. En el libro colectivo titulado Tuñón de Lara el compromiso con la historia incluye también una biografía sobre este historiador español ya fallecido ${ }^{23}$.

En la enseñanza de la historia, en el nivel primario y secundario se está tomando conciencia de la conveniencia de volver a lo biográfico y lo individual como medio de que el alumno sienta más motivación e implicación hacia la historia, la vea como algo más concreto y próximo, y le sea más facil de entender y comprender. La experiencia señala que los niños $y$ adolescentes tienen gran dificultad en captar y entender los procesos económico-sociales, las estructuras en las cuales se desenvuelven los acontecimientos, el tipo de historia basada en conceptos y abstraciones que se les enseñaba en los años setenta y ochenta. Se han realizado algunas experiencias concretas para que el alumno capte lo histórico a traves del conocimiento de su propia historia, partiendo de su propio relato autobiográfico y el de sus padres, abuelos, y personas del entorno. Los resultados han sido satisfactorios pues los alumnos han sido capaces de integrar más coherentemente los acontecimientos históricos del siglo XX, de relacionar su propia realidad e historia con los hechos pasados, han entendido mejor que la historia es la suma de acontecimientos, de pequeñas historias y que su historia personal y familiar tenía puntos en común con la que estudiaban en los libros. Los alumnos estaban más motivados, trabajaban a gusto incluso fuera de las horas de clase, se ilusionaban con el

23 Nora, 1987; Tortella, 1988; Duby, 1992; Jackson, 1993; Fraser, 1990; Beloff, 1992; [TUSElL] 1993; GRANJA y REIG TAPIA, 1993; Le Goff y HEURGon, 1996. 
descubrimiento progresivo de nuevos datos y se cuestionaban el porqué de los acontecimientos vividos por su familia ${ }^{24}$.

Algunas editoriales han captado la vuelta del sujeto a la historiografía y han comenzado a publicar biografías dedicadas al mundo escolar. En 1996 la editorial Anaya ha lanzado al mercado una colección de biografías con tratamiento informativo lleno de motivación dirigido a lectores de doce años en adelante. Cada volumen se dedica a un personaje relevante, cuya vida y obra, contextualizada en su época, permite conocer la historia del periodo. Entre los primeros títulos están, por ejemplo, Cesar y Roma, Picasso y el Mediterraneo, Los Beatles y los años sesenta.

En resumen, el interés por la biografía surge en nuestra sociedad postindustrial y posmoderna donde se puede considerar al individuo que produce, consume y vota como la unidad básica del sistema en torno al cual se articula los saberes y ciencias con el objetivo de examinarlo y comprenderlo desde todos los ángulos y facetas. Así tenemos que la historiografía se interesa por la historia de las personas mientras los historiadores cuentan sus experiencias vitales buscando en ellas su identidad en un ambiente donde prolifera las autobiografías, memorias y testimonios. La filosofía se vuelve a replantear conceptualmente el sujeto, la biología muestra la diversidad génetica del individuo que le distingue radicalmente de sus demás congéneres, la epistemología da una importancia central a la subjetividad, la literatura fusiona el yo imaginario y el yo real, los medios de comunicación explotan con éxito los aspectos más privados y ocultos de lo individual, etc.

\section{LA BIOGRAFÍA EN LOS AÑOS NOVENTA}

Creo que la distinta consideración que presentaba la biografía en los ámbitos historiógraficos españoles durante los años setenta y los noventa queda patente en dos artículos publicados respectivamente por los historiadores Carlos Seco Serrano y Antonio Morales Moya.

Carlos Seco en 1976 atestiguaba que el género biográfico histórico no se encontraba entre las "corrientes y técnicas de última hora", estaba "en baja» en un medio sociocultural caracterizado por el predominio de la masa frente al individuo y un medio historiográfico donde predominaban los cálculos estadísticos con el olvido del hombre idividuo. Carlos Seco intentaba en

24 Asi se indica en López Del Amo, SOLA, 1991, pp. 120-122. 
su artículo reivindicar las ventajas del género biográfico de cara al conocimiento histórico. Apoyaba su argumento fijándose en la historiografía de Annales, por ese tiempo de plena moda en España. Explicaba que la historia total o integral de Fèbvre, Bloch y Braudel quedaba patente en la trayectoria vital de un hombre, donde se manifestaban coordinadas complejamente todas sus funciones de pensamiento, acción y sentimientos. Recordaba la famosa frase de Fèvbre "el método es el hombre» y su insistencia en el estudio de las estructuras determinantes del devenir humano, que incluía el análisis de la específica personalidad humana, tal como el historiador francés lo llevó a cabo en su monografía sobre Lutero ${ }^{25}$.

De todas formas en España había historiadores que se dedicaban al género biográfico. Incluso el introductor de la metodología de Annales en nuestro país, Jaime Vicens Vives, realizó estudios biográficos, por ejemplo Historia crítica de la vida y reinado de Fernando I/ de Aragón (1962). Historiadores tradicionales, en la línea del positivismo historicista, también sacaron a la luz algunas obras, que aportaron luces fundamentales para la consideración de los personajes y su época. Por ejemplo, Fernández Almagro en Cánovas (1951) y Pabón en Cambó. Esta biografía que llega hasta la guerra civil, fue publicada en sucesivos volúmenes durante los años cincuenta y sesenta. Proporciona un minucioso cuadro de la vida política del primer tercio del siglo haciendo girar los acontecimientos en torno a una de sus claves maestras el catalanismo, encarnado en Cambó, el artífice de la Liga Catalana.

Lo que ocurría en la España de los años setenta y ochenta era que la corriente historiográfica con mayor predicamento en ámbitos académicos era la escuela de Annales, que se distinguió por explicar las estructuras socioeconómicas y las masas más que en narrar y comprender trayectorias individuales.

Pero en Francia desde finales de los años sesenta se produce una revalorización social del individuo en su privacidad y con sus libertades cotidianas frente a sistemas abstractos y máquinarias estatales. Los acontecimientos de mayo de 1968 expresan este cambio sociocultural que después alcanzó a la historiografía francesa. Los investigadores vuelven a preguntarse sobre cuáles fueron los intereses, anhelos y vicisitudes que las personas experimentaron en sus vidas particulares y cotidianas. Por otra parte, los éxitos editoriales conseguidos por ciertas biografías animaron a historiadores, incluidos los de Annales, a dirigir sus estudios hacia el

25 SECO, 1976, pp. 107-117. 
género. Es el caso de Georges Duby con Guillaume le Maréchal ou le meilleur chevalier du monde (1984), Mac Ferro con Petain (1987) o Jacques Le Goff con Saint Louis (1996). El gran público lector acogía más favorablemente la biografía que la historia abstracta y el mercado impuso su ley. Proliferaron los ensayos sobre biografía e historia, apareció el término en los diccionarios históricos y se organizaron coloquios con el fin de calibrar la importancia de un género antes considerado menor ${ }^{26}$.

La biografía se redefine como una de las nuevas perspectivas del conocimiento histórico, como un punto de vista que proporciona una peculiar visión del pasado y complementa el estudio de las estructuras de larga, corta o media duración. A finales de los años ochenta, en el libro colectivo Pour une histoire politique, Philippe Levillain reivindica la biografia que sale del mundo propio del personaje y expresa las relaciones entre lo individual y lo colectivo, las conexiones entre el destino personal y las fuerzas circunstanciales, poniendo como ejemplo la obra Fouquet (1987) de D. Dessert que confronta al gran financiero de Luis XIV a través del siglo XVII, el mundo de las finanzas, la corte y la afirmación del absolutismo ${ }^{27}$. Es el tipo de biografía que presenta el destino de un hombre enlazándolo con el análisis de una época. Según Georges Duby conseguir descubrir y precisar esta relación dialéctica entre medio y persona es lo más díficil de la biografía, empeño que ha reflejado en Guillaume le Maréchal donde la vida de un noble del siglo XIII se conecta con los códigos de conducta y rituales de los caballeros medievales.

La biografía, argumentan los historiadores franceses, puede expresar, además, las estructuras históricas a través de la vida de un individuo. De esta forma la biografía complementa la historia estructural pues ciertas personalidades son al mismo tiempo testigos privilegiados y reveladores de su tiempo. Si es cierto, por ejemplo, que el escritor o el arquitecto son productos del medio y de sus referencias ideológicas, y están formados por el conjunto de las estructuras económicas y culturales, son también con fecuencia los que expresan mejor esas estructuras y esas ideologías latentes o enterradas y si pueden parecer avanzados o retrasados respecto a su tiempo, es precisamente porque lo formulan con más claridad que sus contemporáneos ${ }^{28}$.

\footnotetext{
26 El cambio sobre la posición de la biografía histórica en Francia desde los años setenta se refleja, en Konvitz, 1976; PILlorget, 1985; LeVillain, 1988; Dosse, 1992 y Problemes, 1985. El término «historia biográfica» en BURGUIERE, 1991.

LEVILLAín, 1988, pp. 146,158.

28 BURGIERE, 1991, p. 77.
} 
En la misma línea Jacques Le Goff, en 1993, considera válida la biografía que examina en una vida los interrogantes de una investigación histórica, la que analiza en una persona la encarnación de los grandes movimientos de la historia política, económica, social, cultural, la historia de las mentalidades y lo imaginario. Le Goff retoma un camino iniciado por Lucien Fèbvre que en Un destin. Martin Luther (1928) expuso los problemas de la religiosidad del siglo XVI a través del fundador de la reforma protestante ${ }^{29}$. Además para Le Goff la biografía de un hombre comienza cuando se manifiestan los comportamientos por él asumidos. En Saint Louis (1996) intenta «poner de manifiesto que la duración histórica del individuo no se reducía, tal como consideraba la historia biográfica tradicional, al tiempo de su reinado [...] la duración individual comienza en la época en la cual nacieron las ideas, las tradiciones, las sensibilidades que el heredó" ${ }^{30}$. Otra biografía que explica las decisiones y vacilaciones de un estadista en relación con una coyuntura especialmente difícil es Nicolás II, la transition interrompue, une biographie politique (1996), donde la autora Helene Carrière d'Encause mantiene la tesis de que la política del zar ruso hubiera derivado a la democracia si no se hubieran cruzado los bolcheviques.

En España similares reconsideraciones sobre la biografía histórica van produciéndose. En 1991 Antonio Morales Moya da cuenta del resurgir de la biografía en España y en países del entorno. Las causas se deben, según el historiador, a la demanda del público, las nuevas orientaciones historiográficas y la tendencia hacia la individuación ${ }^{31}$.

En los años noventa la prensa ha reflejado el incremento del gusto por las vidas de grandes personajes y la continua publicación de libros biográficos ${ }^{32}$. Las páginas de diarios y revistas han recogido en forma de reseñas y críticas algunas de las obras biográficas que constantemente iban apareciendo en el mercado ${ }^{33}$. La moda biográfica ha llevado incluso a dedicar secciones fijas a relatar sucintamente la trayectoria de personajes claves de la historia de España ${ }^{34}$. En las listas semanales de los

\footnotetext{
LE GoFF, 1995, pp. 161-163.

VIDAL, 1997, p. 13.

MoRAles, 1993, pp. 229-257.

Por ejemplo en El Pais 27-5-1995, 28-12-1996, 3-2-1997, 7-6-1997.

Reseñas y críticas publicadas sobre todo en los suplementos culturales de diarios como $E /$ País, Abc, El Mundo, Diario 16 y La Vanguardia. Un dossier sobre biografias en la revista Qué leer, Barcelona, 8 de febrero de 1997. Los anuarios de El pais de 1995 y 1996 hacen referencia al auge de las biografias y memorias. Los números de la revista Ayer, dedicados al examen de la historiografía producida en cada año de la década de los noventa han ido incluyendo sucesivas re-
} señas de biografías.

34 Sección de El Mundo que aparece los domingos (otoño 1997). 
libros de no ficción más vendidos casi siempre encontramos alguna biografía. Podemos observar el hecho en los listados que publican semanalmente diarios como El País o El Mundo. En el otoño de 1997, aparece entre los libros más vendidos Felipe de España (1997) del hispanista británico Henry Kamen, biografía que reintrerpreta, humanizandola, la figura de un rey muy denostado, sobre todo por la historiografía extranjera ${ }^{35}$. Varias editoriales han lanzado al mercado colecciones de biografías. Entre otras, Espasa, Salvat, Grijalbo, Temas de Hoy, Eudymion, Rueda, Tusquets. Esta última viene otorgando en los últimos años un premio anual para las biografías, autobiografías y memorias denominado Comillas.

Los libros editados que han solicitado ISBN y que han sido catalogados como biografías y memorias han aumentado en los primeros años noventa respecto al quinquenio 1985-1989. Podemos observar en la estadística siguiente ${ }^{36}$ el crecimiento en términos absolutos de las biografías y memorias junto con un cierto aumento porcentual de estos libros en el conjunto de libros de historia y biografía.

\begin{tabular}{ccc}
\hline AÑO & $\begin{array}{c}\text { MATERIA } \\
\text { HISTORIA. BIOGRAFIA }\end{array}$ & $\begin{array}{c}\text { SUBMATERIA } \\
\text { BIOGRAFÍAS. MEMORIAS }\end{array}$ \\
\hline 1985 & 2.509 & 596 \\
1986 & 2.568 & 690 \\
1987 & 2.407 & 638 \\
1988 & 3.124 & 779 \\
1989 & 2.600 & 597 \\
1990 & 3.016 & 845 \\
1991 & 2.988 & 881 \\
1992 & 3.524 & 988 \\
1993 & 2.834 & 707 \\
1994 & 2.781 & 768 \\
1995 & 3.116 & 894 \\
1996 & 2.736 & 655 \\
\hline
\end{tabular}

35 Lista de los libros más vendidos publicada en El Mundo 11-10-1997, p. 20 del suplemento literario "La esfera".

36 Elaborada a partir de los datos de la Agencia Española de ISBN insertos en sus publicaciones periódicas sobre panorámica de la edición española. Estas cifras no concuerdan con la base de datos en CDRom ISBN Libros españoles editados desde 1973 (septiembre 1997) porque en la base informatizada se van suprimiendo las reediciones antiguas conforme se introducen las nuevas. 
No todos los libros publicados bajo la rúbica de biografia están realizados desde la perspectiva de la historiografía académica. Una parte de esa producción editorial está dedicada a glosar superficalmente algunos aspectos de la trayectoria de personajes populares y famosos de la actualidad. Son personajes que lo mismo pueden provenir de la política que de las altas finanzas, del cine, moda, publicidad o del espectáculo en general. Algunas de estas biografías se escriben alrededor de la vida privada y en clave de revelar sucesos escandalosos, raros o picantes con el fin de alcanzar mayor tirada de ventas. Un ejemplo de este tipo de biografías, que suelen ser "no autorizadas", es la de J. Spada: Grace Kelly: Las vidas secretas de la princesa (1987) o las realizadas por Kitty Kelley sobre Nancy Reagan, la actual reina Isabel de Inglaterra y ahora el titulado Los Windsor, radiografía de la familia real británica (1997).

Además están las biografías que, realizadas comunmente por periodistas acreditados, están escritas con pluma agil y suelen articularse sobre algunas de las facetas de la vida y obra de los personajes del momento como miembros de la familia real, políticos, empresarios, escritores, actores, deportistas. Las fuentes informativas básicas para estas biografías provienen de la prensa y de fuentes orales (entrevistas, conversaciones). Algunas pueden clasificarse dentro del denominado periodismo de investigación que también se construye sobre fuentes documentales puntuales. Suelen ser biografías abiertas, es decir, que el personaje sigue vivo. En 1997 biografías periodísticas son las que han publicado, por ejemplo, Pilar Cernuna titulada Ciclón Fraga, Alonso de los Ríos: La verdad sobre Tierno Galván o Carlos Abella: Adolfo Suárez.

Dentro del conjunto de biografías publicadas en los años noventa están las que podemos considerar historiográficas en tanto siguen el método histórico que obliga, entre otras cuestiones, a introducir al personaje dentro de su tiempo. Los biografiados pertenecen al grupo de los protagonistas de la historia. Entre ellos destacan los políticos y estadistas aunque también hay altos personajes provenientes del ejército, iglesia, empresa o del campo intelectual. Personas secundarias, el hombre de a pie, no ha suscitado, de momento, atención biográfica a no ser desde la perspectiva del periodismo o de la historia oral que ha recabado testimonios con vistas más a recoger recuerdos y memoria que a elaborar una biografía histórica que precisa estar basada en un exhaustivo compendio de fuentes documentales aparte de las orales. Ejemplo de utilización de testimonios orales a partir de las confesiones autobiográficas de veintiocho personajes que vivieron el franquismo y la transición es 
Antes de que el tiempo muera en nuestros brazos. Recuerdos y reflexiones de quienes vivieron con Franco (1996) de C. Elordi ${ }^{37}$.

Es en torno a los años noventa cuando acomenten estudios biográficos algunos historiadores ya consagrados que anteriormente habian realizado investigaciones sobre historia social o política. En 1990 publican obras biográficas Alvárez Junco, Santos Juliá, Javier Tusell y Aróstegui. El primero en El emperador del Paralelo. Lerroux y la demagogia populista lleva a cabo a la vez una narración de los acontecimientos y un análisis de los fenómenos políticos, proporcionando una reconstrucción de la vida de Lerroux y una puesta en evidencia de las variables de la coyuntura histórica y del entramado social de la Barcelona de entre siglos. Santos Julia en Azaña, una biografía política. Del Ateneo al Palacio Nacional expone cronológicamente el choque que experimenta el proyecto republicano de Azaña frente a los poderes asentados a su alrededor (Iglesia, militares, clase patronal, partidos políticos...). Tusell y José Calvo en Giménez Fernández, precursor de la democracia en España relatan la respuesta de un intelectual católico en las diversas y variopintas etapas históricas que le tocó vivir. Arostégui en Francisco Largo Caballero en el exilio explica el cambio de Largo Caballero en las circunstancias especiales del exilio.

De estos historiadores Tusell ha proseguido investigaciones biográticas que han cristalizado en publicaciones sobre Franco, Carrero, Maura y y el rey Juan Carlos ${ }^{38}$. Son biografías políticas realizadas «por líneas exteriores" o fijándose en los actos públicos del personaje y no "desde dentro" o deteniéndose en su psicología e intimidad, según la terminología de Jesús Pabón ${ }^{39}$. También para Tusell la óptica de la biografía política no es la de la intimidad de un personaje sino la del grado en que influyó en los acontecimientos más decisivos de su tiempo, considerando que la evolución de los acontecimientos es producto del juego de las circunstancias y de la voluntad de los agentes de la vida pública. Un buen biógrafo tiene que tratar de ser lo más objetivo y distante posible, siempre tratando de comprender y entender las actuaciones del personaje, reduciendo los juicios de valor y huyendo tanto de la proclividad como de la discrepancia hacia el personaje. Además una biografía para que sea verdaderamente

Trabajos que recogen relatos de vida son, por ejemplo, EGIDO, 1995, ALTED y NúNEZ, 1996 y VilanOVA, 1996. Un testimonio de vida que ha quedado como clásico es una obra que fue publicada en ingles en 1972 y en castellano en 1986. Se trata de Escondido. El calvario de Manuel Cortés donde $\mathrm{R}$. Fraser recoge el relato de un socialista que, tras la guerra civil, se mantuvo treinta años oculto para huir de la represión franquista.

38 Tusell, 1992, 1994, 1995; Tusell y Garcia Queipo de Llano, 1993.

PABÓN, 1952-1969, tomo II, p. X. 
relevante debe aportar algo nuevo, utilizar fuentes documentales originales, y conocer la totalidad de la bibliografía sobre la época. Ello faculta al autor para comprender el papel que tuvo el personaje en la vida pública, pues una buena biografía revela no sólo a un personaje sino también a su sociedad y vida pública ${ }^{40}$.

La comprensión del personaje y su época ha sido también el objetivo de publicaciones efectuadas con ocasiòn del aniversario de la muerte de Azaña en 1990 y el del nacimiento de Franco en 1992, dos figuras claves en la historia política de nuestro siglo que han dado lugar a bastantes estudios biográficos.

La recuperación del legado político e intelectual de Azaña, antes denostado por la historiografía franquista y ahora recuperado por demócratas de todo signo, se puso de manifiesto en la obra ya citada de Santos Juliá y en las de José María Marco (1990), Luis Arias (1991), Peña Gonzalez (1991), Ferrer Solá (1991) y Jiménez Losantos (1994) ${ }^{41}$. Además se publicaron varias monografías colectivas que recogian aspectos significativos de la actuación gubernamental y obra intelectual del político republicano que aún resultan válidos para nuestro presente. Se trata del catálogo editado a raíz de la exposición celebrada en el Retiro de Madrid, las actas del congreso celebrado en Montauban y los publicados por la Fundación Colegio del Rey, Ayuntamiento de Getafe y Alianza Editorial ${ }^{42}$.

Sobre Franco, las obras de historiadores españoles y extranjeros incidieron en las causas por las que el general se mantuvo en el poder tantos años. La obra de Tusell (1992), galardonada con el premio Comillas, utiliza materiales inéditos y refiere las circunstancias en que Franco consigue un poder que ya no dejaría; la de Payne (1992) perfila el actuar de Franco en las etapas históricas más esenciales del régimen; la de Paul Preston (1993), que obtuvo considerable éxito editorial, acumula gran cantidad de fuentes y detalles; la coordinada por Suárez Fernández (1993) reproduce las conferencias sobre Franco y su época impartidas en un curso de la Universidad Complutense de Madrid en El Escorial. La monografía de Reig Tapia (1995) contrasta la realidad y el mito de la figura de Franco y la del Bennassar (1996) no revela novedades. Desde perspectivas no historio-

40 Tusell, 1992, pp. 11-12, Tusell y Garcia Queipo de Llano, 1993, pp. 10-16.

4. La referencia concreta de las obras de estos autores y de los posteriormente citados aparece en la bibliografía final. Con el objetivo de aligerarla no he incluido las obras que están suficientemente explícitas en el texto.

42 Ministerio de Cultura, 1990; Almaric y Aubert 1993; Serrano y San Luciano, 1991; Otero 1991; Alted, Egldo y MANCEBo, 1996. 
gráficas sino anecdóticas, literarias, o ficticias con evidentes tomas de posición aparecieron las obras de Peñafiel, Vizcaíno Casas, Vázquez Montalbán y últimamente Vilallonga. En la personalidad y actuación militar de Franco se fijan los militares Blanco Escola (1993), que la contrapone con la del general Rojo, y Casas de la Vega (1995). Los aspectos psicológicos fueron abordados por González Duro (1992).

La figuras de la Casa Real española han sido foco de atención especial y suscitaron biografías que, generalmente, consiguieron gran aceptación por parte del público lector. La figura del rey Juan Carlos, ha sido examinada rigurosamente por los historiadores Powell (1991) y Tusell (1995). Otras biografías, al estar basadas en conversaciones con los protagonistas, resultan sobre todo de interés por la calidad de los testimonios, pueden calificarse más de documentos históricos que de biografía o historiografía propiamente dicha. Se refieren a Juan Carlos (Vilallonga, 1993), la reina (Urbano 1996) y la madre del rey (González Vega, 1995). El padre del rey, Juan de Borbon, ha sido objeto de biográfos no específicamente historiadores como Luis María Ansón, director del diario $A B C$, cuya obra Don Juan (1994) obtuvo gran éxito de ventas tras haber sido lanzada con efectivo despliegue publicitario, que ha sido calificada más que de biografía de libro de memorias del propio Ansón y de otorgar excesivo protagonismo como diseñador de la restauración monárquica a Saínz Rodríguez. Rafael Borrás (1996) sobre documentación ya conocida interpreta la figura de un conde de Barcelona desentendido de ideologías y en continua lucha por la recuperación del trono. El mismo autor ha publicado una biografía sobre Alfonso XIII subtitulada «el rey perjuro» (1997) que ya nos muestra cual es la tesis que pretende demostrar. Figuras de la casa real carlista también han sido objeto de biografías como Carlos VII y Javier de Borbón Parma ${ }^{43}$

Ciertas personalidades políticas han sido objeto de atención biográfica, lo cual no impide que en la bibliografía histórica española sigua existiendo un gran deficit de biografías de políticos, pensadores y hombres públicos que han ocupado el poder ${ }^{43 b i s}$. En 1996 coincidiendo con el aniversario de la muerte de José Antonio Primo de Rivera salieron varias biografías, entre ellas la de Gil Pecharromán se realizó sobre la consulta de todas las

43 Burgo, 1994, Borbon Parma, 1997. Un análisis del papel que Juan Carlos tuvo en la transición según la biografía e historiografía reciente en GonzALEZ CUEVAS, 1997, pp. 37-42.

430is A la falta de estudios biográficos solventes sobre jefes de Estado y de gobierno en los siglos XIX y xx se ha referido el historiador J.P. FuSI (1996, p. 30). Ahi el autor efectúa una selección de los más valiosos publicados hasta el momento. 
fuentes y bibliografía disponibles hasta el momento. En el mismo año se cumplía el aniversario de la muerte de Durruti y de Negrín. Sobre ambos se han editado estudios biográficos aunque no han aportado novedades fundamentales ${ }^{44}$. En el caso de Negrín todavía falta que salgan a la luz fuentes documentales esenciales. En 1997, aniversario del atentado contra Cánovas, José Luis Comellas ha escrito una nueva obra sobre el personaje (ya publicó una en 1965) en la editorial Ariel.

Otras biografías de políticos publicadas últimamente han sido, entre otras, referentes a Canalejas ${ }^{45}$, Sagasta ${ }^{46}$, Claudio Sanchez Albornoz ${ }^{47}$, Santiago Alba ${ }^{48}$, Cambó ${ }^{49}$, Campomanes ${ }^{50}$ y en torno al político liberal e ilustrado Gabriel Ciscar donde el autor examina la transición del antiguo régimen al liberalismo desde la perspectiva de un hombre representativo del periodo ${ }^{51}$. La figura de Maura ha suscitado varios estudios. Aparte del ya citado de Tusell, el realizado por Cristobal Robles (1995) y M. J. González Hernández (1997) donde se vuelve a poner de manifiesto el carácter regeneracionista y democrático del proyecto de estado maurista. En el campo del ensayo biográfico y quizás sirviendo más para conocer al autor que a sus personajes es Juez y parte, quince retratos españoles (1996) donde el líder comunista Santiago Carrillo opina sobre políticos, casi todos principalísimos, con los que tuvo trato de una forma $u$ otra.

Otros historiadores han enfocado sus indagaciones hacía personalidades de ámbitos diversos, caso de $M$. Cabrera que se detuvo en el empresario Urgoiti, Rodríguez González en el inventor del submarino Isaac Peral; López Delgado, en el general y literato Ros de Olano; Cervera Pery en el almirante Topete. Hilari Raguer utilizando amplia documentación inédita, ha biografíado a otro militar, el controvertido general Batet contraponiéndolo con la figura de Franco, y al vicario del cardenal Vidal y Barraquer. Entre las biografías de intelectuales están la de Villacorta que se centra en el pensamiento del tradicionalista Aparisi y Guijarro, la de Fradera sobre Balmes, que estudia al pensador como ejemplo de expresión de tendencias intelectuales en la España del XIX, y la de Federico Suárez sobre Donoso Cortés.

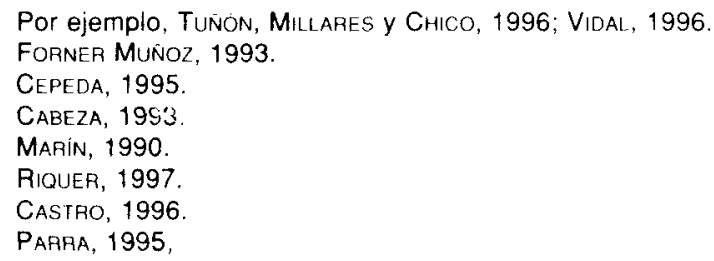


La biografía de corte anglosajón nos ha llegado en los noventa de la mano de hispanistas centrados en grandes personajes de la historia de España. Es el caso de Preston que ha biografiado a Franco. El conde duque de Olivares (1990) del historiador británico J. H. Elliott ha sido considerado como un gran ejemplo de la articulación entre la problemática política de la España del siglo xvil y el intento fracasado de solución reformista llevado a cabo por el valido de Felipe IV. Es un tipo de biografía que, según define Elliot, no le interesa descubrir la intimidad del personaje sino los nexos entre su personalidad y el ambiente de la época, busca saber lo que sucedía en un momento histórico y cómo lo interpretaban los estadistas ${ }^{52}$. El libro de Kamen sobre Felipe II es también otra biografía de un hispanista británico que ha consiguido en 1997 un gran éxito de ventas.

El mercado editorial también se ha enriquecido con biografías de personajes del ámbito exterior al español, realizadas por prestigiosos biografos extranjeros. Por ejemplo, Hitler y Stalin, vidas paralelas (1994) donde el británco A. Bullock hace historia política de Alemania y Rusia a la vez que compara las personalidades y las realizaciones de los dos dictadores; Biografía del poder. Caudillos de la revolución mexicana, 1910-1940 (1997) de E. Krauze donde la revolución mexicana se vuelve más comprensible gracias al examen de los personajes que la dirigieron; El verdadero Lenin (1996) del historiador ruso Dimitri Volkogónov que convierte al dirigente soviético en un tirano sanginario, equiparándole a Stalin. Una biografía que descubre la intidmidad de uno de los grandes científicos de nuestro siglo es Las vidas privadas de Einstein (1996) de Highfield y Cartier que le caracterizan como una persona egoista y cruel. La fabricación de Luis XIV (1995) del historiador de la cultura Peter Burke resulta novedosa en tanto es el relato de la elaboración de la imagen pública del monarca, fraguada durante su propio reinado.

Dentro de los estudios prosopográficos se está produciendo un avance con la publicación de indagaciones sobre personajes de diferentes colectivos. Además de las investigaciones de José Manuel Cuenca Toribio, en torno a las características de los ocupantes de las sucesivas carteras ministeriales en la España contemporánea ${ }^{53}$, han salido al mercado algunos diccionarios biográficos que, basados en documentos primarios y archivísticos, proporcionan la biografia de los componentes de élites políticas, sociales y económicas en el siglos $\mathrm{xIX}$ y $\mathrm{xx}$ de algunas regiones. Ya se han

\footnotetext{
Entrevista a Elliott publicada en El Pais semanal, Madrid, 29-9-1996.

CuenCa y MiRANDA, 1992
} 
publicado diccionarios sobre los parlamentarios castellanos, leoneses y vascos, diputados forales de Navarra y diputados y patricios de Vizcaya ${ }^{54}$. La información proporcionada en estos diccionarios está dando ya lugar a investigaciones prosopográficas, estudios sobre la sociología del poder, importancia de las redes familiares, etc.

De otra clase es el diccionario biográfico, tomo cuarto de la enciclopedia sobre historia de España dirigida por Miguel Artola. Recoge una información sintética, realizada a partir de fuentes bibliográficas, sobre personajes principales ${ }^{55}$. También basado en obras impresas es el Indice biográfico de España, Portugal e Iberoamérica que recoge una enorme cantidad de personajes desde la época romana hasta mediados de nuestro siglo ${ }^{56}$.

En diversos ámbitos académicos también puede detectarse el renovado interés por los estudios biográficos. En 1993 el congreso internacional $A$ historia a debate celebrado en Santiago de Compostela incluyó la biografía entre los retornos historiográficos, junto con la historia narrativa, historia política e historia militar ${ }^{57}$. Tres años antes el congreso internacional de ciencias históricas, celebrado en Madrid durante el mes de agosto, organizó un sección metodológica dedicada expresamente a la biografía histórica dentro de la cual se presentaron numerosas comunicaciones ${ }^{58}$. En los cursos de verano organizados por las universidades se incluyó esta temática: en 1994 la Universidad Menéndez Pelayo organizó los cursos Memorias, biografías y testimonios en la España del siglo xx, dirigido por J. Tusell, e Intelectuales y poder, dirigido por S. Juliá.

Algunas revistas de historia han dedicado sus páginas a la biografía, es el caso de la los dos últimos números de Historia contemporánea de la Universidad del País Vasco que tienen, como tema monográfico los sugerentes títulos relacionados con lo biográfico "A vueltas con el sujeto" $\mathrm{y}$ «Nombres propios para una diplomacia» ${ }^{59}$. Al examen de la vida de importantes salmantinos de los siglos $x \mid x$ y $x x$ está dedicado el no 33-34 (año 1994) de Salamanca. Revista de Estudios. Ahí encontramos a personajes de muy distinto signo, desde el historiados de la ciudad, Villar y Macías, al político J.M. Gil Robles.

\footnotetext{
Carasa, 1997; Garcia-Sanz, 1996; Aguirreazkuenaga, 1993 y 1995.

ARTOLA, 1991

ÍNDICE, 1995.

Actas publicadas en BARROS, 1995

CONGRESO, 1992, pp. 1.093-1.179

Concretamente los números 13-14, año 1996 y número 15, año 1996.
} 
La reaparición del tema biográfico no se ha reflejado prácticamente en las tesis doctorales de historia ${ }^{60}$. Entre las tesis leídas desde el curso 1976 1977 al 1995-1996 que contienen el descriptor "historia" soló alrededor del $3 \%$ de ellas contiene el descriptor «biografías». Es un porcentaje que, punto más, punto menos y exceptuando algunos cursos, se mantiene en los sucesivos años académicos, aunque en los años noventa sí aumentan las cifras absolutas de tesis biográficas como lo hacen las tesis de historia.

\begin{tabular}{|c|c|c|}
\hline \multirow{2}{*}{ Curso académico } & \multicolumn{2}{|c|}{ № de tesis con descriptor } \\
\hline & «historia» & «historia» «biografía» \\
\hline $1976-77$ & 102 & 1 \\
\hline $1977-78$ & 97 & 5 \\
\hline $1978-79$ & 107 & 4 \\
\hline $1979-80$ & 116 & 1 \\
\hline $1980-81$ & 129 & 3 \\
\hline $1981-82$ & 165 & 8 \\
\hline $1982-83$ & 215 & 6 \\
\hline $1983-84$ & 114 & 3 \\
\hline $1984-85$ & 211 & 0 \\
\hline $1985-86$ & 314 & 3 \\
\hline $1986-87$ & 370 & 7 \\
\hline $1987-88$ & 276 & 4 \\
\hline $1988-89$ & 309 & 10 \\
\hline $1989-90$ & 534 & 33 \\
\hline $1990-91$ & 454 & 13 \\
\hline $1991-92$ & 395 & 18 \\
\hline $1992-93$ & 477 & 14 \\
\hline $1993-94$ & 445 & 11 \\
\hline 1994-95 & 495 & 17 \\
\hline $1995-96$ & 522 & 18 \\
\hline
\end{tabular}

Similares resultados se obtienen si contabilizamos las tesis que, con el descriptor "historia», contienen en el resumen el término "biografía". Aunque ahora el porcentaje de tesis biográficas sube al $5 \%$, la cifra también se mantiene a lo largo de los cursos académicos.

50 El examen está realizado en agosto de 1997 sobre la base de datos «en línea" TESEO del Ministerio de Educación y Cultura que recopila las tesis leidas en las universidades españolas desde los años setenta. 
El examen del resumen de las tesis biográficas revela que la mayoria aborda la vida de esas personas desde la óptica de las obras que realizaron. Las investigaciones versan sobre literatos, escultores, pintores, médicos, pedagogos, eclesiásticos, y están efectuadas desde la perspectiva de disciplinas como filología, literatura, periodismo, historia del arte, medicina, ciencias de la educación, teología, etc. Son presentadas y leídas en los departamentos o facultades que imparten y articulan esos conocimientos.

Sólo unas cuantas de las tesis biográficas, conexionan o relacionan la vida, la obra y el tiempo histórico del personaje. En su mayoría están presentadas en las facultades de historia aunque hay algunas leídas en ciencias de la información, económicas y políticas-sociología. La mayoría aborda la trayectoria de políticos españoles (Hervás y Panduro, Roda y Arrieta, A. Capmany, Múñoz Torrero, Letamendi, Argüelles, Madoz, Nicolás Salmerón, Diego Hidalgo, Romanones, A. Maura). Entre ellas hay algunas dedicadas a políticos catalanistas (M. Domingo, Sampere, Martí i Julià). Las hay dedicadas a intelectuales y escritores ( C. Arenal, R. M. de Labra, J. Castillejo, Pérez de Ayala, Echegaray, G. de Balparda, M. Aznar, Pemán), extranjeros relacionados con España (Chateaubriand, El Raisuni, John Langdon-Davies, Emeterio Betances). Hay algunas sobre eclesiásticos (el obispo Morgades, el cardenal Gomá, el obispo carlista Laguera) militares (Emilio Herrera, Ibáñez e Ibáñez de lbero) empresarios (R. de la Sota), historiadores (Jaime Vicens Vives). Curiosamente aunque son escasas las tesis biográficas, algunos personajes se repiten, concretamente los ilustrados Jovellanos y Campomanes y el arzobispo Eijo y Garay.

\section{LA COMPRENSIÓN COMO MÉTODO DE CONOCIMIENTO EN LA BIOGRAFÍA HISTÓRICA}

El rasgo quizás más característico de la nueva biografía histórica es que intenta relacionar los acontecimientos particulares del entorno próximo del biografíado con las causas generales y los grandes movimientos de la época, también trata de revelar las características conformadoras de una sociedad o una política a través de la trayectoria vital de un hombre. Es la forma gracias a la cual la biografía sale de un aislado marco individual y se integra en la historia general. Además los historiadores tratan de sustentarla sobre la consulta de un acervo documental lo más nuevo, exhaustivo y cruzado posible con el fin de conseguir para la biografía la máxima credibilidad científica. 
La biografía actual intenta una conexión que implica comprensión, una forma de conocimiento que junto con la descripción y explicación son propias de la ciencia y de la historia. Son procesos que están fuertemente imbricados. Mediante la descripción definimos y enumeramos las características y actuaciones del sujeto, por la comprensión interpretamos esas características y actuaciones dentro del respectivo contexto histórico. Para comprenderlos tenemos que explicarlos, es decir, contestar a la pregunta ¿por qué se produjeron?. Puede haber varios tipos de explicaciones (causal o por causas antecedentes, genética o cadena de acontecimientos imbricados unos en otros, teleológica o por fines u objetivos consecuentes). Esta última deberá tenerla especialmente en cuenta el biógrafo pues las personas suelen actuar por finalidades especificas. La explicación no puede quedarse sólo en la comprensión empática, es decir, ponerse en el lugar del personaje tratando de sentir lo que él sintió en determinadas circunstancias pues es un método limitado. Por ejemplo, los actos paranoicos realizados por un personaje histórico se explicarian más que identíficandose con él, haciendo referencia a los principios de la psicología patológica. Otras explicaciones nos las puede proporcionar la antropología, sociología, filosofía u otras disciplinas.

La comprensión no es una tarea intelectual fácil ya que para comprender una manera de sentir y vivir, para entender un hombre y una época, es preciso gastar gran cantidad de esfuerzo y tiempo, reconstruyendo pacientemente los hechos a través de huellas y documentos. Cuantos más datos hayan sido examinados y contrastados, cuanto más rica haya sido la experiencia personal, vital e investigadora del historiador más posibilidades tendrá de comprender a sus personajes, es decir, mayor capacidad comprensiva-descriptiva-explicativa para conocer a los biografíados en sus circunstancias espacio-temporales ${ }^{61}$.

Voy a finalizar este artículo poniendo un ejemplo del método de la comprensión en la forma en que yo lo entiendo y tal como lo he puesto en práctica en un estudio biográfico concreto. Trataré de explicar un hecho puntual: la actitud del político Manuel Azaña ante la incorporación de las ciudadanas a la vida política en el año de proclamación de la segunda república ${ }^{62}$.

La pregunta que me propongo contestar es ¿hasta que punto el político republicano por antonomasia, el gran defensor de la modernización y democratización de la vida pública española, consideraba o no básica la

Sobre la comprensión en historia NuÑEZ, 1995, pp. 41-54.

La exposisción más amplia de estas consideraciones en NUÑEZ, 1996, pp. 167-195. 
incorporación de las mujeres a la vida pública? Al principio la respuesta estaba confusa pues advertí hechos contradictorios.

Por un lado, Azaña no había votado a favor del sufragio femenino cuando los oportunos artículos constitucionales fueron sometidos al dictamen del Congreso en 1931 y en los diarios azañistas las diputadas de la primera legislatura republicana no salían muy bien paradas.

Por otro lado, las opiniones de los coetáneos eran dispares sobre la actitud del político alcalaíno. Su inseparable amigo y cuñado Cipriano de Rivas Cherif escribió en Azaña. Retrato de un desconocido (1981) que «quizá por ser naturalmente aficionado a las mujeres, era profundamente antifeminista y si no se tomaba siquisera el trabajo de discutirlo, su opinión y no se diga su sentimiento, estaba siempre en contra de la intervención manifiesta y de derecho de la mujer en la vida pública». En cambio la periodista Josefina Carabias en Los que le llamábamos don Manuel (1980) recuerda que su profesor Luis Jiménez de Asúa, presidente de la comisión parlamentaria encargada de confeccionar la constitución republicana, le había relatado que, en sus conversaciones con los miembros del gobierno, Azaña había estado a favor del voto de las mujeres, argumentando que era una injusticia e indecencia que, a esas alturas de siglo y en un país europeo, se les negase el derecho a elegir y más siendo ya elegibles.

Para comprender el pensamiento y la actitud de Azaña es preciso considerar su posición e intereses políticos, su personalidad, trayectoria vital y las circunstancias históricas:

a) El partido liderado por Azaña, Acción Republicana, junto con los partidos republicanos de izquierda, votaron en contra del sufragio porque, aunque reconocían el principio de igualdad de derechos políticos, no lo consideraban oportuno en ese momento ya que, convencidos de la clericalización radical de las españolas, suponían que votarían mayoritariamente a favor de “los curas y la reacción», poniendo en peligro de desaparición la república laica en trance de implantación.

b) Los escritos de Azaña muestran que estaba persuadido de esa clericalización. Aducía que durante la restauración borbónica la influencia de las esposas y madres sobre los políticos liberales habia frenado la posibilidad de instaurar una política de signo laico. En La velada en Benicarlo (1937) -drama donde introduce muchas de sus ideas y sentimientos sobre la guerra civil- califica la religiosidad de las españolas como uno de los factores del desencadenamiento de la guerra civil en 1936. Asímismo debemos considerar que de niño, en su casa, habia vivido al lado mujeres muy religiosas y su esposa Dolores Rivas era ejemplo de catolicidad practicante. 
c) Pero Azaña, aunque creía en la clericalización de las españolas, pensaba como demócrata que era una injusticia negar el voto a la mitad de la ciudadadanía sólo porque existia la probabilidad de que en futuras elecciones emitiese un sufragio no conveniente para las libertades que la república trataba de instaurar. Porque creía que eso era una injusticia y para no manifestarse contra la opinión de su propio partido, optó por no asistir a las votaciones el 1 de octubre de 1931, cuando se dirimía la cuestión en las Cortes. De esa ausencia le queda tan mala conciencia que en su diario alega una excusa que resulta falsa. Escribe que no estuvo presente en la votación, porque tenía que asistir a una reunión política. Pero a esa reunión también acudieron otros políticos que si depositaron su voto en el Congreso por lo cual su excusa resulta sin fundamento.

d) En cuanto a las ácidas críticas de Azaña a la actuación política de las diputadas, podemos considerarlas del mismo tenor que otras lanzadas a muchos de los diputados y miembros del gobierno. Era una característica de la personalidad de Azaña el ser especialmente sarcástico con sus congéneres, sin hacer distingos respecto a si eran varones o mujeres. Además no todas las opiniones fueron negativas. Tuvo frases favorables para la actuación de Clara Campoamor y Dolores Ibárruri.

En conclusión y contestando a la pregunta que formulaba en líneas anteriores, vemos que hay una dicotomia en la actitud de Azaña ante la incorporación de las mujeres a la política. Creía teórica y lógicamente en ella, de acuerdo con sus propios principios de construir un estado basado en la democracia pero, en el momento preciso no le dió su voto porque entonces pesaron más consideraciones políticas circunstanciales. Sin duda Azaña creía que la clericalización de las españolas podía acabar con el estado republicano laico y tampoco quería oponerse a sus compañeros republicanos que votaron contra el sufragio precisamente por esa razón.

\section{BIBLIOGRAFÍA}

AguiRREAZKuENAGa, J. y otros 1993, Diccionario biográfico de los parlamentarios de Vasconia, 1808-1876, Vitoria, Parlamento Vasco.

Agutrreazkuenaga, J. y otros 1995, Diccionario biográfico de los diputados generales, burócratas y patricios de Bizkaia, 1800-1876, Bilbao, Bizkaio Batzar Nagusiak.

Almaric, J.-P.; Aubert, P. (eds.) 1993, Azaña et son temps jcolloque international, Montauban 2-5 novembre 1991], Madrid, CNRS-GDR 30-Casa de Velázquez-Ville de Montauban.

Alted, A.; Egido, A.; Mancebo, M. F. (eds.) 1996, Manuel Azaña: pensamiento y acción, Madrid, Alianza.

Alted, A.; Nuñez, M.G. 1996, Trayectoria de una anarco-sindicalista sevillana hasta 1939: el testimonio de Maravillas Rodriguez, en SegurA, C.; Nielfa, G. (Eds.), Entre la marginación $y$ el desarrollo: mujeres y hombres en la historia, Madrid, Orto. 
Andrés Gallego, J. 1993, New history, nouvelle histoire. Hacia una nueva historia, Madrid, Actas, 1993.

ARIAS, L.1990, Azaña o el sueño de la razón, Madrid, Nerea.

ARtola, M. (dir.) 1991, Enciclopedia de historia de España, tomo IV, Diccionario biográfico, Madrid, Alianza.

Barros, C. (ed.) 1995, Historia a debate. Actas del congreso internacional celebrado el 7-11 de julio de 1993 en Santiago de Compostela, S. de Compostela, A historia a debate, 3 v.

Blanco Escola, C. 1993, Franco y Rojo. Dos generales para dos Españas. Barcelona, Labor/Escuelas Pies.

BELL, D. 1991, El advenimiento de la sociedad postindustrial, Madrid, Alianza (ed. or. 1973).

BELOFF, M. 1992, An historian in the twentieth century: chapters in intellectual autobiography, New Haven /London, Yale University Press.

Bennassar, B. 1996, Franco, Madrid, Edaf.

Borbon Parma, M. T. 1997, Don Javier, una vida al servidcio de la libertad, Barcelona, Plaza \& Janés.

Borras Betriu, R. 1996, El rey de los rojos. Don Juan de Borbón. Una figura tergiversada, Barcelona, Plaza \& Janés.

Borras Betriu, R. 1997, El rey perjuro. Alfonso XIII, Barcelona, Plaza \& Janés.

BURGiere, A. (dir.) 1991, Diccionario de ciencias históricas, Madrid, Akal.

Burgo Toraes, J. de 1994, Carlos VIl y su tiempo. Leyenda y realidad, Pamplona, Gobierno de Navarra.

Burke, P. (ed.) 1993, Formas de hacer la historia, Madrid, Alianza Editorial.

Cabeza Sanchez-Albornoz, S. 1993. Semblanza histórico-política de Claudio Sánchez Albornoz, Madrid, Fundación Universitaria Española.

Cabrera, M. 1994, La industria, la prensa y la política. Nicolás Maria de Urgoiti 1869-1951, Madrid, Alianza.

CARASA, P. (ed.) 1997, Elites castellanas de la restauración. Diccionario biográfico de parlamentarios castellanos y leoneses 1876-1923, Valladolid, Junta de Castilla y León, 2 v.

CASAS dE la VEGa, R. 1995, Franco militar, Madrid, Fénix.

CAstro, C. de 1996, Campomanes. Estado y reformismo ilustrado, Madrid, Alianza.

CEPEDA ADAN, J. 1995, Sagasta, el político de las horas difíciles, Madrid, Fundación Universitaria Española.

Cervera Pery, J. 1996, Juan Bautista Topete: un almirante para una revolución. Prólogo de J. Ortega Spottorno, Madrid.

COMELtas, J. L. 1997, Cánovas del Castillo, Barcelona, Ariel.

Congreso Internacional. de Ciencias Historicas (17\%, Madrid) 1992, II. Sección cronológica. Metodologia: La biografía histórica, Madrid, Comité Español de Ciencias Históricas.

Cruz, M. 1993, Individuo, modernidad, historia, Madrid, Tecnos.

Cruz, M. (comp.) 1996, Tiempo de subjetividad, Barcelona, Paidós.

Cuenca Toribio, J. M.; Miranda Garcia, S. 1992 Sociologia de los ministros de la restauración (1902-1931), Madrid, Centro de Estudios Constitucionales, 1992 (Separata de la Revista de estudios políticos, n. 75)

DosSE, F. 1992, La historia contemporánea en Francia, en Historia contemporánea, Universidad del País Vasco, n. 7.

DuBY, G. 1992, La historia continúa, Madrid, Debate.

EGIDO, M. A. 1995, Eslabones del quinto regimiento: las milicias regionales. Experiencas y reflexiones de un capitán del "Batallón Segoviano", en en ALTED, A. (coord.), Entre el pasado $y$ el presente. Historia y memoria, Madrid, UNED.

ENGELBerg, E.; Schleier, H. 1992, The contribution made by historical biographies of the 19th and 20th century towards deepening historical biography, en CONGRESO INTERNACIONAL DE CIENCIAS HISTORICAS (179, Madrid), II. Sección cronológica. Metodología: La biografía histórica, Madrid, Comité Español de Ciencias Históricas, p. 1105-1108.

FERNÁNDEZ, J. 1991, Textos autobiográficos españoles de los siglos XVIII, XIX y xx. Bibliografía, en Anthropos, Barcelona, n. 125, octubre, pp. 20-23.

Ferrer Sola, J. 1991, Manuel Azaña: una pasión intelectual, Barcelona, Anthropos.

FoRner MuNoz, S. 1993, Canalejas y el partido liberal democrático, 1900-1910, Madrid, Cátedra.

FraderA, J. M. 1996, Jaume Balmes. Els fornaments racional d'una política católica, Vic, Eumo Editorial. 
Fraser, R. 1990, La formación de un entrevistador, en Historia y fuente oral, Barcelona, núm. 3.

Fusi, J.P. 1996, La jefatura del Estado y del gobierno, en MORAles, A.; Esteban de Vega, M. (eds.), La historia contemporánea en España, Universidad de Salamanca.

Garcia-Sanz Marcotegul, A. 1996, Diccionario biográfico de los diputados forales de Navarra 1840-1931, Pamplona, Gobierno de Navarra.

Gil Pegharroman, J. 1996, José Antonio Primo de Rivera. Retrato de un visionario, Madrid, Temas de hoy.

GonzAlez, W. J. (ed.) 1996, Acción e historia. El objeto de la historia y la teoria de la acción, Universidade da Coruña.

Gonzalez Cuevas, P. C. 1997, El rei taumaturg (la fabricació de Joan Carles I), en L'avenç, Barcelona, n. 212, març.

Gonzalez Hernandez, M. J. 1997, El universo conservador de Antonio Maura. Biografía y proyecto de estado, Madrid, Biblioteca Nueva.

González Vega, J. 1995, Yo, María de Borbón, Madrid, El País-Aguilar.

Gonzalez-Duro, E. 1992, Franco. Una biografía psicológica, Madrid, Temas de hoy.

Granja, J. L. De la; Reig Tapia, Alberto 1993, Manuel Tuñón de Lara. El compromiso con la historia. Su vida y su obra, Universidad del País Vasco.

Í NDICE 1995, Indice biográfico de España, Portugal e Iberoamérica, ed. y dir, por Victor Herrero Mediavilla, Munchen [etc.], 7 v.

JACKSON, Gabriel 1993, Historia de un historiador, Madrid,Anaya/Mario Muchnik.

Jiménez Losantos, Federico 1994, La última salida de Manuel Azaña, Barcelona, Planeta.

Konvitz, J. 1976, Biography: the missing form in French historical studies, en European studies review, London, n. 6.

LE GOFF, J. 1995, Les retours dans l'historiographie française actuelle, en BArros, Carlos (ed.), Historia a debate. Actas del congreso internacional celebrado el 7-11 de julio de 1993 en Santiago de Compostela, S. de Compostela, A historia a debate, v. 3.

Le Goff, J.; Heurgon, M. 1996. Une vie pour l'histoire, Paris, Le Decouverte.

Levillain, P. 1988, en Remond, René (dir.), Pour une histoire politique, Paris, Ed. du Seuil.

López del Amo, I.; Sola Montserrat, R. 1991, Yo también tengo historia, en Historia 16, Madrid, n. 179, marzo.

López Delgado, J. A. 1993, El general Ros de Olano, Murcia.

Loureiro, A. G. (coord.) 1991, Problemas teóricos de la autobiografía, en Suplementos Anthropos, Barcelona, n. 29, diciembre.

LuDWIG, E. 1962, Genio y carácter, Barcelona, Juventud (ed. or. 1924).

LyotaRd, J.F. 1986, La condición posmoderna. Intorme sobre el saber. Madrid, Cátedra (ed. or. 1979).

Marco, J. M. 1990, Azaña, Madrid, Mondadori.

MARIN ARCE, J. M. 1990, Santiago Alba y la crisis de la Restauración, Madrid, UNED.

Ministerio de Cultura, 1990, Azaña [Catálogo de la exposición celebrada en Madrid, noviembre 1990-enero 1991]. Madrid, Ministerio de Cultura.

MONOD, J.1970, Le hasard y la nécesité. Essai sur la hilosophie naturelle de la biologie moderne, Paris, Ed. du Seuil (ed. en castellano, 1972)

Morales Moya, A.1993, Biografía y narración en la historiografía actual, en Problemas actuales de la historia. Terceras Jornadas de Estudios Históricos, Salamanca 1991. Salamanca, Universidad.

Navajas, G. 1996. Más allá de la psomodernidad, Barcelona, Eub.

Nora, P. (comp.), 1987, Essays d'ego-histoire, Paris, Gallimard.

Núnez, M. G. 1995, Historia y ciencia: una relación polémica, en ALtTED, A. (coord.), Entre el pasado y el presente. Historia y memoria, Madrid, UNED.

Núnez, M. G. 1996, Sentimiento y razón: las mujeres en la vida de Azaña, en ALtEd, A.; EGido, A. y ManceBo, M. F., Manuel Azaña: pensamiento y acción, Madrid, Alianza.

Ollivier, S. 1995, Histoires de l'individualisme et individualisme contemporain en France, en BArros, C. (ed.), Historia a debate. Actas del congreso internacional celebrado el 7-11 de julio de 1993 en Santiago de Compostela, S. de Compostela, A historia a debate, v. 2.

OtERo, J. (comp.) 1991, La segunda república española a través del presidente Manuel Azaña en el cincuentenario de su muerte (1940-1990), Getafe, Ayuntamiento.

PABON, J. 1952-1969, Cambó, Barcelona, Alpha, 3 tomos. 
PARRA Lopez, E. la 1995, El regente Gabriel Ciscar. Ciencia y revolución en la España romántica, Madrid, Compañía Literaria.

PAYNE, S. G. 1992, Franco. El perfil de la historia, Madrid, Espasa Calpe.

Peña GonzÁlez, J. 1991, Manuel Azaña, el hombre, el intelectual y el político. Alcalá de Henares, Fundación Colegio del Rey.

Peñafiel, J. 1992, El general y su tropa. Mis recuerdos de la familia Franco, Madrid, Temas de Hoy.

PILLORGET, R. 1985, La biografía, género histórico. Evolución reciente en Francia, en VÁzoUez de Prada, V.; Adao da Fonseca, L.; Floristan, A. (ed.), Las individualidades en historia. Actas de las /l conversaciones internacionales de historia. Pamplona 21-23 de marzo de 1979, Universidad de Navarra.

Plutarco, 1970, Alejandro y César. Vidas paralelas, Madrid, Salvat/Alianza.

Powetl, C. T 1995, Juan Carlos. Un rey para la democracia, Barcelona, Planeta.

Preston, P. 1994, Franco, "Caudillo de España", Barcelona, Grijalbo (ed. or. 1993).

Problemas, 1991. Problemas actuales de la historia. Terceras Jornadas de Estudios Históricos, Salamanca 1991. Salamanca, Universidad.

Problemes, 1985, Problèmes et méthodes de la biographie. Actes du colloque. Sorbonne, 3-4 mai 1985, Paris, Publications de la Sorbonne.

Raguer, H. 1993, Salvador Rial, vicari del cardenal de la pau, Montserrat, Abadia.

Raguer, H.1994, El general Batet, Montserrat, Abadia, (ed. en castellano 1996).

RANKE, L. von 1966, Grandes figuras de la historia, Barcelona, Grijalbo.

ReIG TAPIA, A. 1996, Franco "Caudillo": mito y realidad, Madrid, Tecnos.

Riquer, Borja de 1997, El último Cambó 1936-1947, Barcelona, Grijalbo (ed. or. en catalán 1996)

Robles, C. 1995, Maura, un político liberal, Madrid, CSIC.

Rodriguez Gonzalez, A. R. 1993, Isaac Peral. Historia de una frustración, Murcia, Caja Murcia.

Romera CASTILlo, J. 1991, Panorama de la literatura autobiográfica en España (1975-1991) en Suplementos Anthropos, Barcelona, n. 29, diciembre.

Romera Castillo, J.; Gutierrez Carbajo, F.; Garcia-Pages, M. (eds.), 1996, La novela histórica a fines del siglo Xx, Madrid, Visor.

SEco, C. 1976, La biografia como género historiográfico, en Once ensayos sobre la historia, Madrid, Fundación Juan March.

Serrano, V.A. y San Luciano, J. M. (eds.) 1991, Azaña, Alcalá de Henares, Fundación Colegio del Rey.

STONE, L. 1986, El resurgimiento de la narrativa: reflexiones acerca de una nueva y vieja historia, en STONE, L., El pasado y el presente, México, FCE.

Suarez, F. 1997, Vida y obra de Juan Donoso Cortés, Eunate-Universidad de Navarra.

Suarez Fernandez, L. (coord.) 1993, Franco y su época, Madrid, Actas.

TORTELLA, G. 1988, El método del historiador: reflexiones autobiográficas, en CoLOQuiO DE SEgovia sobre Historia CONTEMPORANEA de EsPAÑa (4ํ, 1987), La segunda república españo1a. Bienio rectificador y Frente Popular, 1934-1936, Madrid, siglo xx।.

TounaIne, A. 1993, Crítica a la modernidad, Madrid, Temas de hoy.

Tunón de Lara, M.; Miralles, M. y Diaz Chico, B. N. 1996, Juan Negrín López. El hombre necesario, Las Palmas, Gobierno de Canarias.

TUSELL, J. 1992, Franco en la guerra civil. Una biografía política, Barcelona, Tusquets.

[TuselL, J.] 1993, La historia. Hablando con Javier Tusell, Madrid, Acento.

TUSELL, J. 1994, Antonio Maura. Una biografía política, Madrid, Alianza.

Tusell, J. 1995, Juan Carlos I. La restauración de la monarquia, Madrid, Temas de hoy.

Tusell, J.; Garcia Queipo de Llano, G. 1993, Carrero. La eminencia gris del régimen de Franco, Madrid, Temas de hoy.

Urbano, P. 1996, La reina, Barcelona, Plaza \& Janés.

Vazouez Montalban, M. 1992, Autobiografía del general Franco, Barcelona, Planeta.

VICENS Vivens, J. 1962, Historia critica de la vida y reinado de Fernando II de Aragón, Zaragoza, Insititución Fernando el Católico.

VIDAL, C. 1996, Durruti. La furia libertaria, Madrid, Temas de hoy.

VIDAL, J. C. 1997, San Luis o el difícil arte de la biografía, El País, Madrid, 30 de agosto, p. 13 del suplemento literario Babelia.

VILALlongA, J. L. 1993, El rey, Barcelona, Plaza \& Janés. 
VILALLONGA, J. L. 1997, El sable del caudillo, Barcelona, Plaza \& Janés.

VILALLONGA, M. 1996, Las mayorias invisibles. Explotación fabril, revolución y represión, 26 entrevistas, Barcelona, Icaria.

VILLACORTA, J. L. 1990, La derrota intelectual del carlismo: Aparisi y Guijarro trente al siglo, Bilbao, Instituto Diocesano de Teología y Pastoral.

Vizcaino CaSAS, F. 1992, 1975/El año en que Franco murió en la cama, Barcelona, Planeta.

WatZlawick, P. y Krieg, P. (comp.) 1994, El ojo del observador, Barcelona, Gedisa. 